\title{
Russian BeCKett: PARAdOXEs OF PERCEPTION
}

\author{
NADEZHDA PROZOROVA
}

\section{Introduction: Hermeneutical aspects of Beckett's work}

This essay is focused on hermeneutical aspects of Samuel Beckett's work. To be precise - on the problems of their perception and interpretation in contemporary Russia in the situation of "revaluation of values" that is typical of the new fin de siécle.

One of the founders of modern philosophical hermeneutics the German philosopher Hans-Georg Gadamer claimed that to understand a text meant to apply it to ourselves (Gadamer 1991: 329). According to Gadamer, we always apply the work of any writer to our contemporary situation, to a given context connected with an interpreter. Thus, the main hermeneutical procedure of application (Anwendung) reminds us of the plurability and mutability of interpretation. From the point of view of hermeneutical Anwendung the works of Beckett are of special interest for contemporary Russia in the transitional period of its history.

Let us start with some impressions of personal nature concerning Beckett's works. I first came across the name of Beckett in the early 1960s when I was a student in Moscow State Lomonosov University. I was given the English version of Waiting for Godot and can remember the play having the taste of the Forbidden Fruit for me. ${ }^{1}$ I was shocked by the strangeness of that play without plot and action, with its hollow dialogue, with that desperate first remark of Estragon "Nothing to be done" and with its wonderful Gospel story of two thieves, "crucified at the same time with our Saviour". In those times, many people approached all dramatic texts assuming that drama, as Shakespeare once put it, must "hold the mirror up to nature" in its most literal sense (Shakespeare 1994: 689). With time, reading the play again and again, seeing its productions, I

\footnotetext{
${ }^{1}$ The first Russian translation from French version of the play made by M. Bogoslovskaya was published in 1966 in the journal Inostrannaya Literatura [Foreign Literature], Issue 10, with a short introduction where the play was presented as an example of the "destructive tendencies" of the theatre of the absurd. Almost thirty years later, in 1994, there appeared a new translation of Waiting made by Alexander Sergievsky and Alexander Yarin from English version of the play. It was published in the journal of drama, Sufleur. Jurnal Zarubezhnoy Dramaturgii, Issue 1. The presentation of this issue took place in the Russian State Library of Foreign Literature in spring 1994 and it was widely commented on by the Irish press. In particular, The Irish Times commentary on this event mentioned the importance of "launching" Beckett's play in Moscow.
} 
realised the meaning of Beckett's first American director Alan Schneider's saying, "Waiting for Godot is no longer a play, but a condition of life" (Schneider 1975: 27). In fact, that tragicomedy written in French in 1949, translated by its author into English in 1954 and now available in over twenty languages, becomes for me "a mirror" of the human tragic consciousness, a mighty metaphor of life as a process of the everlasting 'waiting' and an expressive parable with its threnody to wasted lives.

\section{Russian Beckett, his perception and its paradoxes}

As far as some general aspects of Russian Beckett are concerned, they are really connected with a number of paradoxes. These paradoxes reflect both - the paradoxical character of Russian contemporary historical experience and the paradoxes of Beckett's creative personality. Beckett declared his preference for art which is "the expression that there is nothing to express, nothing with which to express, no power to express, no desire to express, together with the obligation to express" (Esslin 1965: 17). His own art is an attempt to enclose "nothingness in words" as he wrote in one of his poems.

Thus, I would like to mention the first paradox concerning our perception of Beckett's works: it is really strange to search for sense in nonsense. Our perception of Beckett is inseparable from our attempts to make sense out of Beckett's terrifying void. In his late play What and Where Beckett provokingly states, "Make sense who may". But it turned out that the Beckettian metaphysics of the absurd revealed something tragic and actual in Russian experience of the last century that is "the anguish of man without God". Recently, two volumes of works by a famous Polish philosopher, theologian, catholic priest and public figure Józef Tischner have been published in Russia. In his essay on Emmanuel Levinas, Tischner claims that if we do not find the infinite essence - God - we would be devoured by the sense of the absurd, as "the only cause of destruction of sense is the death of God” (Tischner 2005: 136). Beckett's works give us such cause to ponder upon the implication of this claim as well as upon the implication of Clive S. Lewis' saying, "If we cannot "practise the presence of God", it is something to practise the absence of God" (Lewis 1960: 128). In the works of Beckett we find a similar demonstration of God's existence ex absentia resulting in a tragic feeling of man's abandonment. This feeling is clearly expressed by Beckett's Mrs. Rooney in his play All That Fall: "We are alone. There is no one to ask" (Beckett 1957: 29). This makes Beckett strikingly akin to existentialist European thinkers and writers from Kierkegaard to Kafka, including Russian existential tradition that begins with Dostoyevsky.

I think it would not be a mistake to claim that Russian perception of Beckett's work is connected with a tendency of delving deeply into its philosophic content, although Beckett always refused to allow any philosophical meaning or thesis to be attributed to his works. Beckett, as is well-known, often 
repeated that he was not an intellectual and some of his critics called him a man who managed to live without a head. Indeed, Beckett is free of any abstract conceptions or general ideas. Reducing human life to its essentials he, as an artist, was more interested in the form of expression than in its content. Among Beckett's rare public utterances about general considerations underlying the work of creative artists we can find the following statement suggested by St. Augustine's sentence about the two thieves on the cross (it is also known to suggest one of the motifs in Waiting for Godot):

I take no side. I am interested in the shapes of ideas... There is a wonderful sentence in Augustine: "Do not despair; one of the thieves was saved. Do not presume; one of the thieves was damned". That sentence has a wonderful shape. It is the shape that matters (Esslin 1965: 4).

Perhaps, our inclination to a philosophical interpretation of Beckett's work was partly conditioned by the publications of Russian Silver Age religious philosophers whose works were inaccessible for Russian readers till the late 1980s. The works by Sergey Bulgakov, Evgeny Trubetskoy, Pavel Florensky and some others affected to a considerable extent our perception and interpretation of Beckett. Let me give only one example. It is well-known that the artistic world of Beckett is that of endless repetition where nothing new can happen. As Estragon in Waiting for Godot claims: "Nothing happens, nobody comes, nobody goes, it's awful” (Beckett 1965: 41). E. Trubetskoy in his work The Meaning of Being uses the concept of endless repetition as a metaphor of hell. He points out that hell is deeply rooted in our real world which we can see and uses the image of Sisyphus as the emblem of a ghostly activity which has no sense and no end (Trubetskoy 2000: 39). In the context of this discourse we can feel more deeply both the tragic notes of Beckett's work and the dramatic incompleteness of our own historical experience which reminds us about James Joyce's well-known saying of the "nightmare of history".

Another paradox concerns what might be termed a chronological inversion of Russian perception of Beckett. Our changing historical and literary context of a new fin de siécle resulted in the phenomenon of the so-called "returned literature": that is, increasing publications of works by those authors who were forbidden in the Soviet period. The returned literature is connected with the names of those writers who emigrated from the country after the revolution or those who were persecuted in the Stalinist period. Among the latter were Daniil Kharms and Alexander Vvedensky. In the late 1920s they organized an Association of Real Art (OBERIU) in Leningrad, where the provocative "real" had nothing to do with the reflection of reality. "Oberiuty" as the members of this Association are called created their own reality of free imagination where all traditional links of the world's phenomena were destroyed and where "the logic of 
infinite non-being” dominated, if we can use the title of one of Kharms' poems. Like Beckett, Oberiuty wrote poems, plays and prose works searching for new means of expression. Like Beckett, they questioned the traditional concept of reality as "the known world with known values" and turned the idea of the absurd into the main category of their texts. In 1937, not long before his arrest, Kharms wrote in his diary that he was interested only in nonsense, in that which had no practical value. Thus, Oberiuty might be considered to be the predecessors of the Western European absurd literary movement. But Russian readers paradoxically perceived them as a post-Beckettian phenomenon with Beckettian oxymoronic unity of "merriment and mud" and with Beckettian strange poetry lightened by the "star of nonsense", the image offered by A. Vvedensky. Let me cite a fragment of his poem Around Might Be God:

The star of nonsense is ever shining,

And it is always lonesome.

A dead gentleman comes rushing in

And he is silently removing time (Vvedenskij 1993: 152, my trans.).

Beckett's literary status is also radically changed in the present-day Russia. Instead of being regarded a shocking destroyer of all traditional literary forms as it was not so long ago, he is considered now to be a recognised classic, a writer of great devotion to this art. The ideas expressed in the concluding passage of Beckett's first biography written by Deirdre Bair are really akin to Russian perception of Beckett's artistic personality nowadays:

In all of this century, it would be difficult to come upon another writer who has so lived through his art that it has become the substance of his life. Beckett himself insists that his life is "dull and without interest. The professors know more about it than I do". He abhors the interest in his person and insists with intense sincerity that "nothing matters but the writing. There has been nothing else worthwhile".

Over and over again, he has said... "I couldn't have gone through the awful wretched mess of life without having left a stain upon the silence".

(Bair 1978: 640)

Silence is a very important concept in the artistic world of Beckett. Action is constantly arrested in silence in his plays. The interaction of words and silences makes his plays be akin to musical composition. For Russian readers and theatregoers it reminds of Chekhov's artistic technique where the concept of silence is also of great importance and can carry many meanings. It can suggest an inability to express, as through the excess of feeling or stupefaction, it can refer to what language cannot express or it can convey the doubt if there is anything yet to express. 
In this connection, let me recall 1989, when the International Theatre Congress on Stanislavsky took place in Moscow and when Russian theatre-goers had the opportunity to see the best productions of famous European directors, timed to this Congress, including Peter Brook's production of Chekhov's The Cherry Orchard with his International Actors group. Thinking back on my first impressions, I can now realise that the Beckettian context must have helped to see this well-known Chekhov's play in a new light. For Brook's production was really a Beckettian one in its oxymoronic unity of tragedy and comedy, in its almost bare stage, in its complex interaction of words and silences. It is appropriate to mention as well that Brook was one of the first theatre directors who had grasped a sense of likeness between Chekhov's and Beckett's dramatic techniques. In particular, he saw their similarity in the principal importance of their phrase rhythm when placing the comma, or the three dots timed speech one way rather than another. That is why Brook was not satisfied with any of the numerous English translations of Chekhov's play. For his Moscow production he used a new translation made by Elizabeth Lavrova who tried to be as faithful rhythmically to the original as possible. Brook's Moscow performance of The Cherry Orchard, very musical in its structure, reminded me about Pozzo's wellknown saying in Waiting for Godot, "Have you not done tormenting me with your accursed time!” (Beckett 1965: 89). Brook presented Chekhov's play as an existential drama of human beings plunged into "accursed time" but longing for the eternal.

And it is in the 1980s that the theatre life of Beckett's plays was beginning in Russia. Russian theatrical Beckett also began with Waiting for Godot more than thirty years after the famous premiere of the play in Paris. It was produced by Alexey Levinsky at the Satire Theatre in Moscow and the producer played Vladimir in that performance. Representing the aesthetics of the "poor theatre" with its scenic asceticism and restraint of scenic expression, Levinsky found in Beckett the most suitable playwright for realisation of his theatrical ideas. Levinsky's production of Waiting for Godot was a very successful attempt to challenge the primacy of psychological theatre in Russia. It was in many ways adequate to Anouilh's well-known judgement after the first Paris performance of the play. Jean Anouilh saw in that performance a strange combination of farce played by clowns and the tragic notes of Pascal's Pensées. The actors of Levinsky's production with their baggy pants and farce games ("shoes off", "shoes on") looked like traditional clowns coming from the music hall or the circus. But the effect of the performance was more tragic than comic. Levinsky's clowns in their ghostly activity and vain expectations were filled with existential sadness. The audience felt compassion for them like that for their predecessor, the pitiful figure of the early Chaplin.

During the last two decades Levinsky continued productions of Beckett's plays. The most successful of them was his Play after Beckett's dramatic 
miniatures. Levinsky managed to evoke by theatrical means Beckett's everpresent feeling of uncertainty which Russian audience was ready to share. Beckett always expressed a position of doubt about the external world. His artistic universe is that of "chaosmos" if we use James Joyce's famous pun. The queer idea of inseparability of chaos and cosmos, mess and order became one of the fundamental principles of modern non-classical science. Beckett made that paradoxical "chaosmos" the foundation of his vision of life. His creative activity, according to his own saying, was an attempt "to find a form to accommodate the mess". But Beckett extended his doubt to the inner reality of our personal existence. As his Mr. Rooney in All That Fall said: “Don’t take any notice of me. I do not exist. The fact is well-known" (Beckett 1957: 15).

Though Beckett's theatre life in Russia began after a long delay, it nevertheless happened perhaps in due time. It turned out that Beckett's plays found themselves in an appropriate literary and theatrical context. They had much in common with the Russian "new wave" drama that was springing up in the 1970s and the 1980s. In plays by Ludmila Petrushevskaya or Nina Sadur with their artistic principle of reductio ad absurdum the Russian audience could grasp their likeness to Beckett's theatre of the absurd. And in the 1990s, the time came for Beckett's late plays, such as What and Where or Catastrophe marked with a political implication, namely that of totalitarianism. They helped to correct our former perception of Beckett as an ivory-tower figure, though his plays were not the direct exposure of political problems but rather parables with universal connotations and with a kind of parody of agitprop plays. I would like to note that the Russian Beckett had his public success as a dramatist and it is through his plays that he should be approached by most Russian people, though his novels are at least of equal importance and some critics have referred to the plays as dramatic footnotes to the novels.

\section{Conclusion}

In conclusion, let me address the problem of Beckett's national status that is also of much interest for Russian mentality. An Irishman who spent the most part of his life out of Ireland and who "oscillated" between two languages, English and French, Beckett nevertheless always revealed his Celtic roots. His Irishness displayed itself in his queer logic of paradox, his macabre humour and his linguistic restlessness. Beckett's obsession with philosophical and communicative aspects of language has much in common with Joyce, Yeats or Synge, thus reminding us of the logocentric character of Irish culture as a whole. Beckett's characters are aware of how their identity is dependent on the words they use, on the treacherous language where words never correspond to reality. So Dan Rooney, in that most Irish of Beckett's plays, All That Fall, tells his wife: "Do you know, Maddy, sometimes one would think you were struggling with a dead language". And when she agrees he adds: "Well, you know, it will be dead in 
time, just like our own poor Gaelic...” (Beckett 1957: 32). Beckett made us notice the danger of meaningless abstractions offered by language and resulted in its "death". Russian culture with its dominance of word has much in common with Irish "logocentrism". Thus Beckett's works attract our attention to a complex character of national identity that escapes any exhaustive definition and that is very appropriate for present-day Russia, first of all due to the phenomenon of its emigrant literature, the so-called Russian literature abroad.

I am well aware that "Russian Beckett" is not a subject which can be readily exhausted or summed up. Let me, however, offer one closing and summarising observation.

George Berkeley, Beckett's fellow-countryman, once claimed: "Esse est percipi" (To be is to be perceived). And for a writer's being as a writer it is certainly true, as his work exists only in the minds of those who read it. The process of Russian perception of Beckett is connected with radical changes in the optics of our vision. Something outer and alien unexpectedly becomes inner and native when we apply the works by this "splendidly mad Irishman" to our own experience. Beckett's works help us to feel the unity of European cultural tradition and the common fate of "all that fall".

Let me conclude my paper by citing a poem by Zinaida Hippius written in September 1917. It is entitled Why and concerns the mystery of the Slavic attraction to the Celtic world:

Oh, Ireland, the ocean shell,

I have never seen your glens,

Why does than your mysterious swell

Lull the clarity of my sense?

Why do I think of your foamed line?

And of seagulls that scream at dawn?

Is it me sailing through the veil of time

Into universe memory turned?

Oh Erin, unknown isle!

Oh Russia, my native land!

Isn't each of us ever trialled

And to Calvary torment condemned? (Hippius 1999: 219, my trans.)

Kaluga State University, Russia 


\section{References}

Bair, D., 1978, Samuel Beckett. A Biography, London: Johnathan Cape.

Beckett, S., 1957, All That Fall. A Play for Radio, London: Faber \& Faber.

Beckett, S., 1965, Waiting for Godot. A Tragicomedy in Two Acts, London Boston ( $2^{\text {nd }}$ ed.): Faber \& Faber.

Esslin, M., ed., 1965, Samuel Beckett. A Collection of Critical Essays, New Jersey: Englewood Cliffs.

Gadamer, H.-G., 1991, Aktyal'nost' Prekrasnogo [The Relevance of the Beautiful], Moscow: Iskusstvo. Transl. from German, Die Aktualität des Schönen, Stuttgart: Phillip Reclam, 1977.

Hippius, Z. N., 1999, Stihotvorenija [Poems], Saint Petersburg: Academ Proekt.

Lewis, C. S., 1960, The Four Loves, London and Glasgow: Clear-Type Press.

Schneider, A., 1975, “Any Way You Like, Alan': Waiting with Beckett', in: Theatre Quarterly 5:19 (September - November).

Shakespeare, W., 1994, 'Hamlet, Prince of Denmark', in: The Complete Works of William Shakespeare, Ware, Hertfordshire: The Shakespeare Head Press Edition.

Tischner, J., 2005, Izbrannoje, $v$ dvuh tomah, t. 1. Myshlenie $v$ kategorijah cennosti [Selected Works, in Two Volumes, vol. 1. Cognition in the Categories of Value], Moscow: Rosspen.

Trubetskoy, E. N., 2000, Smysl zhizni [The Meaning of Being], Moscow: Folio.

Vvedenskij, A. I., 1993, Polnoye sobranije proizvedenij, $v$ dvuh tomah, $t$. 1: Proizvedenija 1926-1937 [The Complete Works, in Two Volumes, vol. 1. Works, 1926-1937], Moscow: Gileja. 